\title{
'WAR HISTORY ON SCRAPS OF PAPER': EXHIBITIONS OF DOCUMENTS AT THE AUSTRALIAN WAR MEMORIAL, 1922-1954
}

\author{
ANNE-MARIE CONDÉ
}

Public History ReVIeW, vol 14, 2007, pP25-43

\begin{abstract}
n January 1954, a new display opened at the Australian War Memorial in
Canberra. The building had been open to the public since 1941, and its

exhibitions had become popular attractions for locals and interstate visitors. But the 1954 display, small though it was, represented a new departure, and the partial fulfillment of an ambition long-held by the Memorial's founders. It was a documents exhibition. It drew on the Memorial's abundant collections of archives and printed material and was held in the Library. The exhibition was noticed by the press. 'War history on scraps of paper', began a report in the Melbourne Herald. It went on: 'Much of Australia's military history has been written in lead pencil on scraps of paper, as well as in blood on distant shores.' This was the first time documents had formed almost the sole focus for a display, albeit temporary, at the Memorial. It formed a contrast to uniforms, works of art, weapons and large technology pieces that constituted most of the Memorial's exhibitions. The other exhibitions were striking and exciting but, as the Herald's reporter noticed, the events that had shaped Australia's military history could also be read on mere 'scraps of paper'. ${ }^{2}$

While a display of documents alone was new, the Memorial had always incorporated documents into its major exhibitions which, until the permanent building in Canberra opened in 1941, were held in Melbourne and Sydney. Moreover, it had for many years maintained a collection of exhibition-worthy documents, either acquired for exhibition purposes or kept separate from other groups of records. And there were even hopes that there could be a permanent gallery in the Memorial's building in Canberra devoted solely to the display of documents. My purpose in this article is to draw out and discuss these activities and ideas, focusing on the period from the opening of the first major exhibition in 1922 in Melbourne until, and slightly beyond, the 1954 temporary documents exhibition in Canberra. I want to explore the material selected, the meanings were ascribed to it, how it was managed within the Memorial's collections, and the relationships it had with the three-dimensional
\end{abstract}




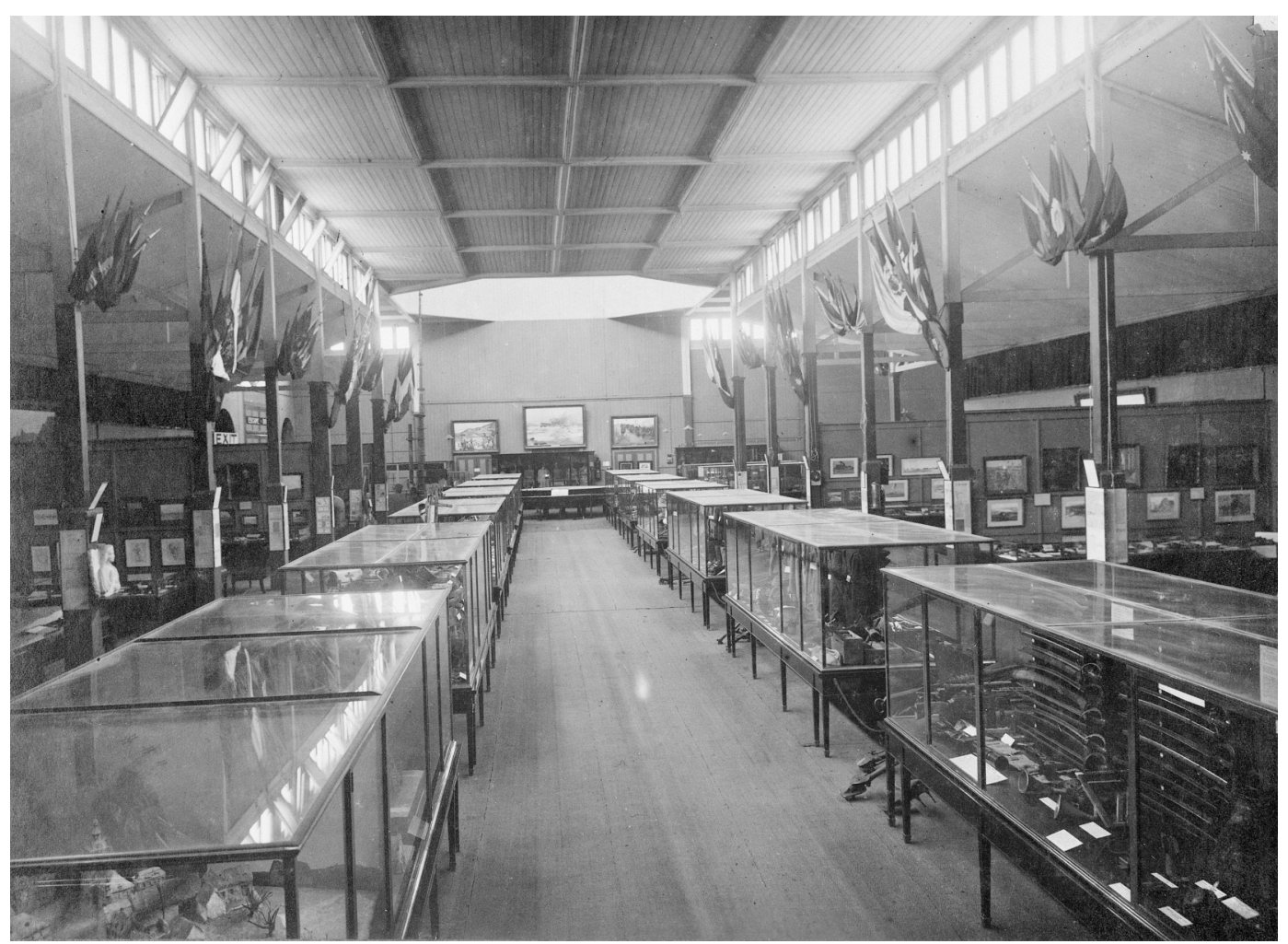

The Exhibition Building in Melbourne housed this, the first major exhibition held by the Australian War Museum (later Memorial). It opened in April 1922. In amongst the plethora of material were documents (Australian War Memorial negative number J00290)

objects. How might it have been represented to the visitor? What chain of imaginings and memories did it generate? In short, I want to wonder at and analyse the power of the document, not just for its content as represented literally by the words on paper, but for its properties as an artefact.

This means addressing some gaps and challenges in the history of museum exhibitions in Australia. Museum histories seldom analyse the history of history exhibitions in any detail, and rarely consider the display of documents. ${ }^{3}$ Secondly, records of what was on display in past exhibitions and how it was selected can be hard to come by. They form part of an institution's own archives and these might not be well described or easily accessible to the public. ${ }^{4}$ And as anyone who has worked on an exhibition knows, records of the activity of mounting an exhibition are not always kept, or kept systematically, and do not always lend themselves to being neatly filed. A further challenge, finally, relates to insights in museology developed since the 1980s, principally that visitors derive and make meanings from museum exhibitions based on their own life experiences and memories. 'What happens in museums is more than the cold meeting of the minds of visitors with the curator's carefully constructed displays,' Gaynor Kavanagh has remarked. 'Both curators and visitors make meanings. ${ }^{5}$ Janis Wilton discusses the meanings created by critics and founding collectors as well as curators and communities. ${ }^{6}$ On communities, the American museologist Ivan Karp puts it most succinctly: when people enter 


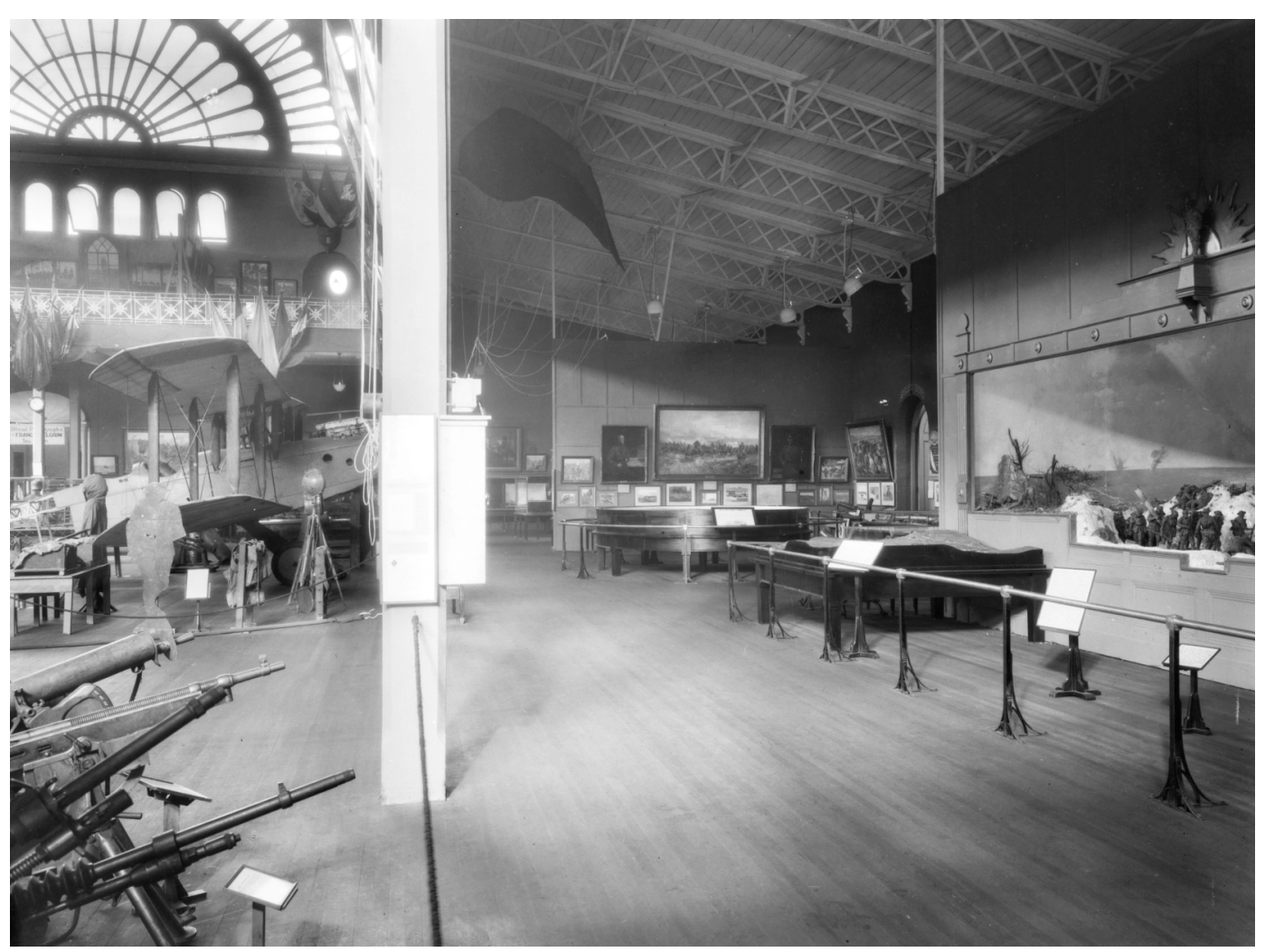

The exhibition as it appeared in Sydney at the Exhibition Building at Prince Alfred Park from 1925 until 1935 (Australian War Memorial negative number J02198)

museums, he says, 'they do not leave their cultures and identities in the coatroom. ${ }^{7}$ But how are we to open this up to historical analysis? How might museum practitioners from the past have understood these processes? This is a challenge that few museum historians in Australia have attempted. Even though the Australian War Memorial has a long and, in places, well documented exhibitions history, it is not easy, at this distance, to capture the conversations between curators and visitors generated by long-past exhibitions. But throughout this article I have tried to offer this perspective where possible.

Museum history offers a little guidance in this discussion, but archives history hardly any. The slow but gratifying development of archives history in Australia has barely touched on the area of archives exhibitions or other 'outreach' activities. ${ }^{8}$ Archives theory has developed out of the processes of creation, acquisition and control of records and archives. Outreach has been a poor cousin, sometimes regarded as marginal to the core business of the archives program, something to undertake only 'when everything else that archivists do is neatly and tidily done. ${ }^{9}$ It seems that the treatment of outreach in archives, as a field of historical enquiry, also lags behind. This may change. In the last couple of decades most major archives have developed sophisticated outreach and exhibition programs, both physically and on-line, and there is a discernable thread of professional literature flowing from it. ${ }^{10}$ Archivists might still feel it is too soon to subject archival outreach to historical 
analysis but I propose not to wait. We shall not bother with neatness and tidiness, but take a risk.

\section{A Memorialising Collection}

Before proceeding, however, we do need to pause a moment to consider the origins of the collections of the Australian War Memorial, the better to understand the impulses that later guided the exhibitions.

An 'Australian War Records Section' (AWRS) was formed in London in May 1917 under a young army officer, Lieutenant John Treloar. ${ }^{11}$ The immediate purpose of the AWRS was to collect and organise the documentary record of the Australian forces so that it could be preserved for Australia rather than be absorbed into Britain's records. Later in 1917 the AWRS began collecting and commissioning a wide range of material including photographs, objects, art, printed material and film. The AWRS had been formed at the prompting of Charles Bean, Australia's official war correspondent, soon to be appointed official historian. Bean was impressed with the work the Canadians were doing under Max Aitken (from 1916 Lord Beaverbrook) in establishing in London a Canadian War Records Office (CWRO) for the collection and preservation of its records. A self-made man, Beaverbrook likewise made the CWRO after his own ideas. To the discomfort of the Dominion Archivist of Canada, Arthur Doughty - who was an advocate for professional archival practice - the CWRO was not above creating and, indeed, fabricating records in order to promote the story of Canada's achievements in the war. ${ }^{12}$ The AWRS, on the other hand, had no responsibility for publicity and propaganda and Bean objected privately to Beaverbrook's sanctioning of doctoring and faking photographs. ${ }^{13}$ Bean was not opposed to publicity but at the AWRS official photographers were instructed to regard photographs as 'a sacred record - standing for future generations to see for ever the plain, simple truth. ${ }^{14}$ There is no evidence of any transfer to the AWRS of archival theory or practice of the day. Instead, it was guided by Treloar's experience with military recordkeeping procedures and, more broadly, by Bean's faithfulness to 'the plain, simple truth'.

In developing his ideas about how Australia's war could be commemorated at home, Bean and a group of supporters suggested a memorial consisting of a museum and a library as well as a shrine to Australia's war dead. Successful lobbying, mainly by Bean, guided this idea into being with the establishment in 1919 of the Australian War Museum (later Memorial), based on the collections accumulated by the AWRS. Other countries, such as Britain and Canada, operated in circumstances which led to the separation of collections from commemoration. In Australia they were all one, and the different types of collection material stood both as historic evidence and as a memorial to the dead. In subsequent years Bean wrote often about how the spirit of the dead was present in the collection. He said in 1928:

From the first the object of those who collected for this museum was to make it as human as possible. It contains the atmosphere, the spirit and the relics of 
the A.I.F., and I think we would lose a great deal if we separated these things from the memorial. ${ }^{15}$

The terms 'relic' and 'record' were used at the Memorial very loosely, often interchangeably. 'Relics' in one context were 'records' in another. A work of art could be an historical record as well as an aesthetic expression appealing to the emotions. The Memorial's famous collection of dioramas is probably the most significant example of that. ${ }^{16}$ And in 1948 Bean referred to the entire collection of the Australian War Memorial as 'the record' made by Australians who had served and died. ${ }^{17}$

\section{A 'DOCUMENTS GALLERY'}

Back to 1917. As officer-in-charge of the AWRS, John Treloar now had a perfect opportunity to demonstrate his administrative brilliance. As he got down to work with at first only a small staff, he paid heed to his surroundings which happened at that time to be two rooms in the Public Record Office (PRO) in Chancery Lane in London. The Section was based there for less than twelve months but Treloar, a man of high intelligence and curiosity, was mightily taken with the PRO in a number of ways. The records passing through his own hands were contemporary records, mainly the unit war diaries of the Australian Imperial Force (AIF), but the PRO, Treloar knew, was responsible for 'the records of England from the time when record keeping first began.' As he recalled, 'they [staff at the PRO] will show you with great pride' the 'original Domesday Book and... the log of the 'Victory' recording Nelson's death'. He also remembered the 'regimental rolls of British units for all time, and also the nominal rolls of convict ships that came to Australia'. The convict records were not on available for inspection ${ }^{18}$ but from his comments it seems that the rest were on some kind of public access, if not on exhibition. ${ }^{19}$ They probably struck Treloar, who had of course been educated mainly in British history, as being examples of quintessential historical records. Probably with this in mind, he urged Australian military units to do nothing to prevent their own records passing 'into the possession of the Australian nation. ${ }^{20}$ Recalling the PRO records displays as late as 1950 , he hoped that with the planned enlargements to the Memorial's building in Canberra there would be a 'documents gallery' in which there could be 'frequent brief exhibition[s] of collections of documents. ${ }^{21}$

Charles Bean also cherished such an expectation. In early 1918, at the time when Treloar was at the PRO every day, the two men shared lodgings in Kensington while Bean had a brief spell from the front. Here they talked 'night after night' about their plans for a war memorial in Australia one day. ${ }^{22}$ By March 1918, Bean was in a position to begin outlining his proposals for an Australian war memorial, possibly in the form of a series of federal and state-based memorials, to the Australian Defence Minister, George Pearce. For the institution in Canberra there could be three parts, Bean suggested: a Museum, a Library and a Gallery. In the Library there could be 'the museum of documents - maps captured from the enemy, interesting German orders, historic operations maps and aeroplane photographs'. ${ }^{23}$ Later in 1918, Bean 
mentioned his ideas for an Australian war memorial in Canberra in his book In your hands Australians. In a building on some hilltop, 'still, beautiful, gleaming white and silent' there would be in the library displays of documents that 'had their part in making history. ${ }^{24}$ In April 1919, in a much longer memo to Pearce, Bean expanded again on the idea of an 'Australian War Library', suggesting that there could be private rooms which would be for the use of 'students' who had military approval to look at unit diaries and similar records. But one public room could be filled with 'exhibits' such as the map on which battle of Pozières was fought, the original operation order for the landing at Gallipoli, messages of particular interest, captured documents and the original illustrations from The Anzac Book. Another room could be filled with albums and displays of photographs. ${ }^{25}$

This outline for Peace is important because it shows Bean (and Treloar, for Bean acknowledged that he drew on Treloar's ideas) ${ }^{26}$ grappling with the concept of public access to records. At this time there was no public record office and no archives legislation in Australia allowing for public access to any kind of government records. Records being used by Bean at any one time would be housed with him and therefore be unavailable to the public, and a little later some records were declared confidential. ${ }^{27}$ But from the earliest days there was clearly an imperative to allow the public to see as many records as possible of Australia at war. The Memorial's Library was established in Melbourne by 1922 in a city office building though not with the Memorial's public displays at the Exhibition Buildings in Carlton. But members of the public were invited to use it. ${ }^{28}$ And during the 1920 s both Bean and Treloar thought of producing a book of documents, 'reproductions of important messages, orders etc' at the time an accepted way of offering access to archives - although nothing ever came of either attempt. ${ }^{29}$ Bean's idea for a documents gallery needs to be seen in the context of these ideas about access. He pursued it again in 1928, outlining in evidence to a Senate Committee the concept of a 'museum room' at the Memorial, the first gallery that visitors would encounter. Here would be displayed 'documents and maps of special interest.' Visitor would then move 'through a natural circuit' through the rooms containing 'relics', models and art. ${ }^{30}$

In the event, many difficulties had to be overcome before the building's design and layout were agreed upon and in that fraught process the idea of a documents gallery seems to have been quietly shelved. Documents were, however, incorporated into the Memorial's mainstream exhibitions, as we shall see. What we can take from our discussion of the 'documents gallery' concept is how early it appeared in the planning for the Memorial and how persistent it was.

\section{'We WANT ORIGINALS': THE MELBOURNE AND SYDNEY EXHIBITIONS}

The Australian War Museum ${ }^{31}$ opened its first major exhibition at the Exhibition Building in Melbourne on 24 April 1922. On show was a selection of the material from the vast amount acquired and shipped to Australia by the Australian War Records Section. The Melbourne exhibition was curated by Treloar, who had been appointed Director in 1920. A lengthy guidebook was written by Bean for the Melbourne 


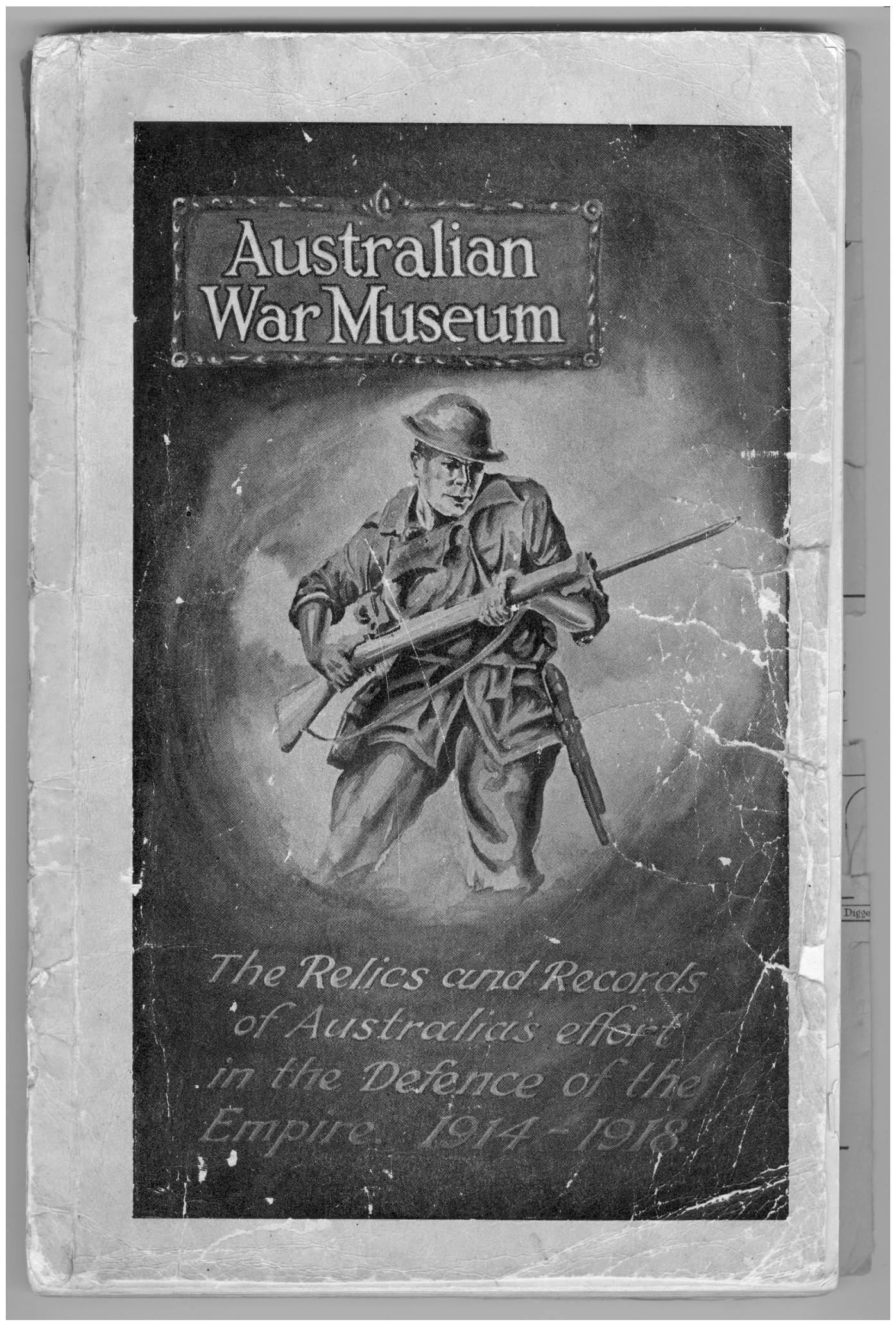

Cover of the guidebook to the Melbourne exhibition (Australian War Memorial) 
exhibition and adapted later for the Sydney show. ${ }^{32}$ In 1925 the exhibition was transferred to Sydney, to the Exhibition Building (since demolished) at Prince Alfred Park. In the meantime the permanent building in Canberra was being designed and built and in 1935 the Sydney exhibition closed in preparation for the transfer of the exhibition to Canberra. The new building opened to the public on 11 November 1941 with exhibitions re-arranged to suit, but very similar to those seen in Melbourne and Sydney.

In all three locations there were things on display that were physically very powerful: a lifeboat used at the landing on Gallipoli, a British Mark IV tank, naval guns, artillery pieces, aircraft, plan models and dioramas, huge battle paintings and mass displays of small arms, uniforms and flags. But documents were an important part of the displays. After settling in Tuggeranong, near Canberra, and beginning work the official history, Bean began offering items 'of great interest' for the Memorial's exhibition which he extracted from the Gallipoli records. He kept copies for his own use and sent the originals to Treloar in Melbourne. These included, in particular, a document from John Monash's records: a copy of a draft signal ordering the lowering of boats for the landing at Gallipoli in the early hours of 25 April. ${ }^{33}$ In February 1921, Treloar wrote to one of Bean's assistants, Arthur Bazley, asking him to make a further selection of about twenty-four documents. He wanted orders for 'important operations'; congratulatory messages or orders; tributes to the work of Australians; propaganda dropped over Australian lines by the Turks from the air; 'interesting' panorama drawings or maps; and telegrams reporting progress of operations, especially for the landing, Lone Pine and the evacuation. From Treloar's list, which he also applied in principle to the selection of records for France and Belgium, ${ }^{34}$ we can get a taste of the curatorial thinking that he was applying. It was a list arranged around key moments in the Gallipoli campaign, or at least ones that the public were likely to know. It seemed designed to foster pride in the Australian actions and it had an eye to what would be visually easy for the viewer. Treloar stressed that the documents must not contain 'over-much writing' as it was unlikely that the public would read them. And, he wrote, 'we want originals'. Bazley would have to make copies and insert them into their places in the records, mostly unit war diaries. $^{35}$

What, then, was finally exhibited? For the Melbourne and Sydney exhibitions there are three ways of knowing. Firstly there are Bean's guidebooks, although these mention documents only occasionally. Secondly, for display purposes the documents were placed in cardboard mounts with Treloar's label text hand-painted on the mounts. Some were never returned to their places in the original records and there they remain today, still in the mounts, like insects preserved in amber. ${ }^{36}$ From these we can see some, though by no means all, of the exhibition documents accompanied by their 1920s text. Finally, there is an inventory of exhibits, dated November 1929, listing most of the objects, documents and art on display at that time in the Sydney exhibition. ${ }^{37}$ It is arranged by location within the exhibition so to an extent we can intellectually recreate the arrangement and relationships of objects. 
It seems then that there were fewer operational orders than Treloar had envisaged but congratulatory documents were there. ${ }^{38}$ Typical is a pair of documents displayed on each side of a cardboard mount. On one side is General Rawlinson's message to the Australians when they left the line early in October 1918 after having taken 'a prominent part' in the 'decisive defeat' of the Germans. On the other is a 1919 message from Marshal Foch, supreme commander of all the Allied forces on the Western Front, that the Australians, 'by their initiative, their fighting spirit, their magnificent ardour, they proved themselves to be shock troops of the first order. ${ }^{39}$ This was the sort of thing that a grieving community needed to hear. More common still were battlefield messages sent directly from the fighting front to the rear. These are the single most common type of exhibition document. One reads: 'Have nearly all our officers casualties... Urgently in need of re-inforcements.' The text accompanying this document has broken off the mount and with no other contextual information associated with it, we can never know what horrible situation it records. ${ }^{40}$ Another message, one that gained particular attention, gave news of fighting near Quinn's Post on Gallipoli on 3 May: 'The situation here is that we hold the ridge in front of the hill by the thirteenth and'. There the writing finishes. A different handwriting at the bottom notes, as does the accompanying text, that the signaler was shot before he could finish the message. He was killed in the very act of making a record. ${ }^{41}$ Messages like this worked because they were short, usually only a page, and the viewer did not need to absorb the operational detail to be struck by the fact that they recorded humanity in the most extreme situations.

Messages, orders and tributes were lifted from unit diaries but there were other sources of documents for display. A large part of the museum collections had been acquired from soldiers responding to a request to pass souvenirs and battlefield detritus to officers of the AWRS for placement in museums (ultimately, the Australian War Memorial) in Australia. A glance through the accession registers compiled by the AWRS at the end of the war show that enthusiastic soldier-gatherers collected an astounding variety of material, including many documents. ${ }^{42}$ Many were souvenired documents of German origin, such as this, written in blue pencil on the brown wallpaper of a German headquarters: 'Tommy! You are the meening to win! As you belive! I think else, You will loose it, and that is the troo! Good by! ${ }^{43}$ Another is a luncheon menu found in a former German headquarters in October 1918. Soup, cold pheasant and potato salad had been enjoyed by the German officers before the town was overrun a fortnight later by Australians. ${ }^{44}$ Documents like this snatch a moment from the past that might otherwise be lost and unknowable. As records they might have been more familiar to the average ex-soldier-visitor and more comprehensible to civilians than documents derived from official records. The Sydney exhibition inventory shows other documentary material of wide appeal: documents and ephemera from enemy and allied forces, including British and German ration cards, foreign currency, newspapers, posters and cartoons. ${ }^{45}$

From the Sydney exhibition inventory and from the museum guidebook of the same date we can learn something of how the exhibits were arranged in 1929. In the 
'Gallipoli Court', there was a display of eight documents. There was one of the first messages from Major Hugh Quinn, reporting the establishment of the famous post on Gallipoli that would take his name. ${ }^{46}$ Nearby, in an instance of 'striking symbolism' according to the guidebook - was some galvanised iron that covered parts of the Australian line at Quinn's Post - 'the most dangerous trenches at Anzac'. It is shot 'through and through'. ${ }^{47}$ Another of the documents was a wireless message relating to the evacuation of Gallipoli. ${ }^{48}$ This was a glance away was William Wallace Anderson's Evacuation, the first sculpture acquired for the Memorial's art collection. It shows an Australian soldier, his foot on a Turkish flag, in an attitude that 'sought to portray the mood in which Australians received the order to evacuate the position they had wrested from the Turks. ${ }^{49}$ Similarly, three documents representing the action at Lone Pine were within easy eye-reach of Wallace Anderson's diorama dramatically depicting the same events in three-dimensional form. ${ }^{50}$ One of the actual pine logs from the Turkish trenches at Lone Pine was also there, scrawled with the names of some Australians who held the position. ${ }^{51}$ The different kinds of material objects, photographs, documents and art - were to be read together. The documents grounded the visitor in the day-to-day detail of events and lent a sense of authenticity to the rest of the display, as if to say 'these things really happened'. The objects and art in turn drew out and enhanced the symbolic and emotional significance of the documents. Altogether, the items on display were not, we are told in the guidebook, as 'battlefield curios' but as 'emblems of those splendid qualities which made the Australian soldier... "the greatest individual fighter in the world.",52

Historian Kimberley Webber has seized upon these words in her discussion of the ways in which the Melbourne and Sydney exhibitions transformed the Memorial's collection of ordinary objects into 'symbols of national greatness', which were invested with 'distinctly spiritual qualities'. The landing at Gallipoli, she says, changed Australia from 'a nation with no interest in history or historical collections to one where both formed a central focus of national identity'. She quotes Bean's belief that the 'relics' of the First World War were 'full of the story of the AIF... with as much history and sanctity attaching to them as the bones of Captain Cook'. Artifacts in the Memorial's collection were 'an opportunity for veneration rather than discussion', she says, and were 'not valued for their information content.' Writing in 1986 in the leadup to the 1988 Bicentenary, Webber concludes on a note of unease. Would the recent growth in museums and historic sites in the 1980s be an opportunity to 'teach us about our past', she wondered, or would they simply provide more 'secular temples at which we can worship? ${ }^{53}$ The years since then have indeed seen many developments in history museums in Australia at local, state and national levels. But curators and historians are now aware that 'teaching' in museums must take place within the context of the memories, life experiences and learning styles that museum visitors bring with them. If visitors are inclined to 'venerate' an object or a document, they probably know something about it already, and therein lies an opportunity for the curator to lead the visitor from the known to the unknown, which is the essence of teaching. 
As Craig Melrose has suggested, Webber pushed her argument too far. ${ }^{54}$ If we look again at Bean's words we note that he referred to 'history' as well as 'sanctity'. His guidebook and Treloar's museum labels were enormously detailed and very didactic. Visitors were expected to follow a set path through the displays and the labels that have survived are extremely wordy by today's standards. Treloar's expertise in military recordkeeping is very much on show. There was far more text to read than any curator or historian would dare offer today, and this to an audience of people who had lived through a war which had ended only a few years before. While it is obviously true that objects were being used in an emblematic way, there was an urgency to teach visitors about the past as well and the documents played a distinct part in this.

More importantly, the documents were a critical part of exhibitions that told human stories about ordinary people. They invited empathy, an important part of learning. Museums in Australia had not done this before, or at least not consciously. Most were museums of science, technology, natural history or art. They did not lack collections of historical material, including paper-based material, as Chris Healy has shown. But as he further points out, colonial museums in Australia 'were without human beings and without human history. ${ }^{, 55}$ The notice taken from a wall in Amiens advising the local people to evacuate before a German bombardment is an instance of Treloar trying to humanize his story. ${ }^{56}$ So too is a paybook of an officer wounded at Lone Pine ${ }^{57}$ and likewise the message left unfinished because the signaler who had been killed. This particular document and other paper items attracted the attention of a journalist for the Melbourne Herald reporting on the opening of the Melbourne exhibition in April 1922. He and many other correspondents noticed the variety of material on display and the stories it could tell and he led his report with a quote from it. 'Nothing is missing from this amazing collection', he proclaimed. 'It would rank as great if it stopped where all other museums are content to stop - as mere technical collections... But that is only the beginning... Its strength and its value to Australia lie in its thousands of intimate personal relics contributed by the fighting men themselves. ${ }^{58}$ The selection of objects and documents for exhibition were part of an attempt to fashion an heroic image of the Australian soldier but they also spoke directly to visitors in a new way, in a language of emotion: humour and sadness, hope and fear. And visitor numbers were astounding: 776,810 visitors went through the turnstiles in Melbourne; and in Sydney, between April 1925 and February 1934, there were $2,313,682$ visitors. Over three million visitors in a nine-year period took the opportunity to view archives. ${ }^{59}$

\section{RELICS, RECORDS AND MEMORIES}

Many of the documents - although not the ephemera - on display in Sydney in 1929 were removed from display in March 1933. ${ }^{60}$ When the Memorial opened permanently in Canberra in November 1941 most of the documents do not seem to have been re-instated in the displays, although it is uncertain why. Nevertheless, in the meantime, the Memorial continued to acquire and separate documents for the 


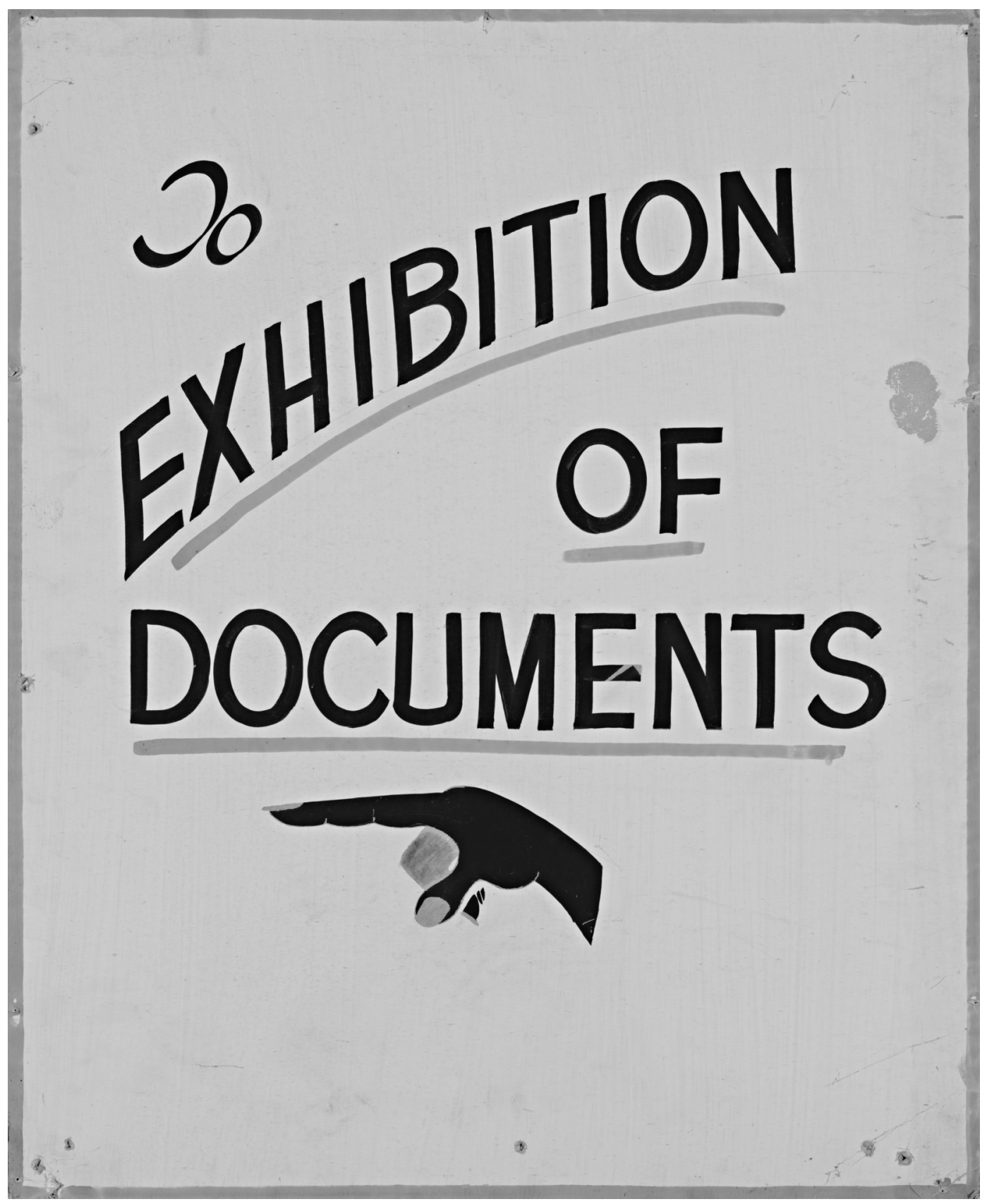

Sign directing visitors to the 1954 documents exhibition in the Memorial's Library (Australian War Memorial Official Records series AWM344 item 1)

sole purpose of exhibition. They were treated as a distinct group, known as 'Exhibition Documents' and kept separate from the larger archival collections. They were allocated numbers: 'Exhibition Document 1', 'Exhibition Document 2'. Some were exhibited in the temporary documents exhibition in the Library in 1954 and new items were added intermittently until the early 1980s, when, under the increasing influence of newly-appointed professional archivists, the practice finally ceased in favour of exhibiting documents from already acquired donations and series and 
returning them thence when no longer needed for display. The 'Exhibition Documents' as a group, however, have been generally left intact. When the Memorial introduced computer cataloguing in the 1980s, 'Exhibition document' was reduced to the prefix 'Exdoc' and for convenience I shall use that term in this discussion.

There are about 170 Exdocs today. ${ }^{61}$ Some have been exhibited several times but with others it is impossible to tell when, or if, they have ever been exhibited. The provenance of many is difficult to establish; in some cases it has not been documented at all. Just under half are associated with the First World War, reflecting the fact that most were acquired when that conflict was the Memorial's main or only priority. Just under a quarter relate to the Second World War and the rest are associated with the colonial conflicts, Korea and Vietnam. Most Exdocs run to only one page but many are not easy to read or visually interesting, throwing the onus of interpretation on to the accompanying label and the general context of the display. Of the First World War Exdocs, most are from army operations on the western front, especially 1916, the year of some of the most dreadful battles for the Australians. Other Exdocs represent the Memorial's documentary share of events on a world stage: the assassination of Archduke Franz Ferdinand in 1914, documents associated with Nazi Germany and the dropping of atomic bombs on Japan in $1945 .{ }^{62}$ A couple of Exdocs are very old and while they say little about Australian military history they can be read as an attempt by the Memorial to connect Australian experience with a much longer British military tradition. One of these documents, for instance, is a certificate dated 1806 awarding prize money to a member of the Royal Marines for the capture of French and Spanish vessels at the Battle of Trafalgar in $1805 .{ }^{63}$

By contrast, there is a group of documents of obvious historic and symbolic significance for Australia: a set of instruments of surrender signed by the Japanese at the end of the Second World War. ${ }^{64}$ Some are facsimiles, others are originals. Looking at them, the eye is immediately drawn to the Japanese signatures. Perhaps many a veteran of the Pacific war has gazed at these and pondered the moment when, by the formation of these strokes on the page, the war - and his own war came to a formal end. But while it is easy to see why the surrenders make it as exhibition documents why are there so many 'visitors' books' in the Exdoc collection? These are records associated with recreational clubs for members of the Australian forces overseas. Visitors signed their names as they arrived, as in any club. The first acquisitions of this type were made in 1946: it was the visitors' books of the 'Boomerang Club', established in the basement of Australia House in London during the Second World War and used primarily by air force personnel on leave. Also of interest (but ultimately never received) was a kitchen door from the club covered in signatures. ${ }^{65}$ Visitors' books were later acquired from clubs in London, New York, Rome, Paris and Japan. Why? Probably because they evoked memories. Visitors to the Memorial who had patronized these clubs would see more than mere signatures on a page. They would recall the place, the times, the chance to relax, write home, sing and dance, enjoy good food and good fellowship before returning to the 
business of war. These are not living memories any more. Supporting photographs, for instance of the Boomerang Club, allow us to imagine all this. Otherwise, the visitors books are uncommunicative records.

The Exdocs collection grew in a rather haphazard way, occupying a middle ground between 'relics' and 'records'. In 1947 Treloar forced himself to confront this issue when he received a donation of papers associated with the underground evacuation of Allied airmen brought down in enemy occupied territory in Europe during the Second World War. Fascinated, he wrote to the donor, a Belgian woman named Anne Brusselmans, for an account of her work with the underground movement in Belgium. But the management of the records, which included interview reports with downed airmen, some publications and newscuttings, puzzled him. By then the Exdocs system was well established and run by staff in the Memorial's Library. But it seems that some documents with exhibition potential were still being accessioned into the museum collections as if they were three-dimensional objects. At first Treloar thought that the Brusselmans material should be treated this way, for he found it of interest as 'relics rather than as records'. But after worrying himself over the matter, he changed his mind and directed that it be managed through the Library. The printed material was to be accessioned as library material, which suggests that it was valued for its informational content alone, and the interview reports were placed with the Exhibition Documents. Treloar still thought the reports were 'unimportant as historical records', so to him their primary value apparently lay in their exhibition potential rather than as historical evidence. ${ }^{66}$

Acquiring single documents from larger groups and keeping them separate for the purposes of exhibition was and is contrary to accepted archival practice. Single items take their meaning and authority from their relationship to the group of records to which they belong, and this should be a 'natural accumulation' of records, not collected for some future purpose. ${ }^{67}$ Paul Hasluck, looking back in 1981 over his years of contact with archives administration as an historian, is blunt on this point. Archives, he insisted, are not created 'to provide a supply of bright specimens for the curious'. Let libraries and museums collect 'the curiosa, the personalia and the detached bits of paper,' he continues, 'but do not call them archives. ${ }^{68}$ If Hasluck made these remarks with the Memorial in mind, and he knew the institution and its people well, it was unkind and probably unjust. No other public collecting institution in Australia faced the challenge of managing a diverse collection with a commemorative function overlaying the library, museum and archives responsibilities. The Exdocs system was a good place to deposit material that was paper-based but which was not kept primarily for its evidential significance. The items were 'paper objects', we might say. Their particular power was in evoking memories and stirring emotions. Their meaning was derived less from their original context than from the powerful new memorialising 'context' imposed upon them.

\section{AND BEYOND}

Treloar did not live to see the 1954 exhibition of documents in the Library. He died in 
January 1952. With his keen eye for publicity for the Memorial, he would have enjoyed the press notice given by the Herald. ${ }^{69}$ Readers were told that they could see a pencilled order to Australian forces to hold the town of Tobruk, a document that marked the beginning of that 'epic siege'. Also to be seen was draft signal ordering the landing at Gallipoli which Bean had offered for exhibition in 1920: 'Queen to all transports - lower all boats ready to send into beach. Pass on'. Also there was a 'scrawled, unsigned draft' of the congratulatory signal which MacArthur sent to Blamey after the capture of Kokoda. A message written by an obscure lieutenant from the First World War 'written in a light but steady hand', declared that 'If [his] section cannot remain here alive it will remain here dead, but in any case it will remain here'. This 'very soldierly document' was one that Treloar hoped to include in the 'documents gallery'. ${ }^{70}$ There was a selection of documents from several wars showing how the enemy had tried to induce Australians to surrender. Across a 'typically-arrogant' German propaganda leaflet from the First World War was the similarly 'typical' Australian observation: "What a lot of Ferdinand"'. There was a Japanese survey map stolen by Australian prisoners of war, its loss apparently hindering the construction of the Burma-Thailand railway. The choice of document was obviously framed around events legendary and iconic, as well as some still in recent, painful memory. By alterations to the Memorial's Act in 1952, the Memorial was now able to collect and exhibit material associated with all Australia's wars, so in this documents exhibition it was able to boast of its newly expanded scope. Material from the Sudan conflict, the Boer War and the Korean War was on display. A typed, roneoed insert into the Memorial's guidebook drew visitors' attention to the documents exhibition. The documents were drawn from a 'special section of the library and represent as cross-section of the type of significant record which wars produce. ${ }^{71}$ This must surely have been the Exdocs.

The exhibition was temporary and not especially prominent - not quite the 'documents gallery' that Treloar and Bean had hoped for - but it was a significant expression of the long-held view that documents could be displayed in their own setting to offer visitors a concept of how, as Bean put it in 1918, they had 'had their part in making history'. Official records were fundamental to the origins of the Memorial and Bean and Treloar, as historian and recordkeeper respectively, had an affinity with them. In describing the concept of the Memorial both invariably spoke of them first. Everything else depended upon the diversity, completeness and accuracy of the written records. In seeking to write the 'truest history that was every written', ${ }^{72}$ Bean based his official history upon them, and they underpinned and validated all of the historical interpretation that the Memorial offered. It was therefore natural that there should be a gallery set aside to display documents. But counterpointed against this was the practice of integrating documents within the mainstream exhibitions not just for their literal meaning and to lend legitimacy to everything else on display, but to do the same evocative work as the 'relics'. And why not? 'It is a bias of literate people', the American historian James O'Toole has warned, 'to think that records, books, manuscripts, and other materials mean only what the words in them mean.' 
Closer examination shows that there are layers of meaning - practical, symbolic, cultural - embedded in record making and in the records that are made. ${ }^{73}$ Canadian archivist Hugh Taylor goes further, urging his colleagues to explore the way users of archives draw on memory and imagination when they interact with the material. If museums can conduct an 'argument with society' to partially answer the question 'What does it mean to be a human being?', he says, cannot archives do the same? ${ }^{74}$

The short guide to the 1954 exhibition of documents told visitors about the Memorial's Library and described its different parts: Printed Records, Written Records, Photographs and Film. If visitors had questions about any of the documents on display, Library staff would be 'pleased to assist'. Here we can see a glimmer of the idea that animates archives programs today in their 'outreach' and 'public programs' activities: to take the collection out into the community and to promote the services the archives can offer. At the Memorial it flowered properly in the 1980s with the transformation of the old Library into a new 'Research Centre' with a full set of reference services; by a series of published guides to collections; with the microfilming and distribution of high-use records; and, at last, with a major, long-term exhibition, 'The Records of War', which ran - with changing displays - from 1988 until 1997. That exhibition coincided, perhaps was even ahead of, similar exhibition projects being developed in other archives in which archivists' confidence in interpreting their collections for exhibitions has grown, as has their openness to learn the skills and methods of curators and museum historians. The Australian Archives, ${ }^{, 75}$ exhibition 'Between two worlds', which told stories about the removal of Aboriginal children from their parents in the Northern Territory, was a major boost to the idea that archives can be used to tell 'a powerful living story'. ${ }^{\text {' }}$

Where this confidence flags, this discussion might help. It supports Helen Nosworthy's suggestion that there is no reason for archivists to entertain any selfdoubt concerning the relevance of archives in the general community. The needs and interests of the public are as important as those of the 'serious' scholar. ${ }^{77}$ Nor should museum curators and historians ignore the power of documents in favour of threedimensional objects which might seem to have more appeal. Exhibitions, as an outreach activity, can be more than just tools for marketing and promotion for archives, important though that is. As Gabrielle Hyslop puts it, archives and libraries can join with museums in 'contributing to ongoing conversations about Australian culture, Australian history and Australian experience. ${ }^{78}$ In stimulating these conversations we must accept that the endeavour is not always going to be 'neat and tidy'. It will involve a complex mixture of professional skills and a willingness to allow for visitors' curiosity, learning, 'veneration' and remembering.

\section{ENDNOTES}

\footnotetext{
${ }^{1}$ For assistance and comments on drafts, I thank Jennifer Coombes, Gabrielle Hyslop, Peter Londey, Brad Manera, Katherine Pawley, lan Smith and Tim Sherratt.

${ }^{2}$ Herald, 12 January 1954.
} 
${ }^{3}$ For institutional histories with good coverage of exhibitions see: Carolyn Rassmussen, $A$ Musuem for the People: a History of Museum Victoria and its Predecessors 1854-2000, Scribe Publications, Carlton North, 2001; Michael McKernan, Here is Their Spirit: a History of the Australian War Memorial 1917-1990, Australian War Memorial and University of Queensland Press, Canberra, 1991. For a relevant British account, see Gaynor Kavanagh, Museums and the First World War: a Social History, Leicester University Press, London, 1994. More generally see: Tony Bennett, The Birth of the Museum: History, Theory, Politics, Routledge, London, 1995; and Chris Healy, From the Ruins of Colonialism: History as Social Memory, Cambridge University Press, Cambridge, 1997. On exhibitions history, see Craig Melrose, 'A praise that never ages: the Australian War Memorial and the 'national' interpretation of the First World War, 1922-35', thesis presented to the University of Queensland, 2004; Ross Gibson, 'Exhibiting', and Tim Sherratt, 'Remembering Lawrence Hargrave', both in Graeme Davison and Kimberley Webber (eds), Yesterday's Tomorrows: the Powerhouse Museum and its Precursors 1880-2005, Powerhouse Museum and UNSW Press, Sydney, 2005. For some years before the opening of the National Museum of Australia in 2001 there was discussion among Australian historians and curators about how Australian history would be represented in the museum. See especially: Proceedings of the Museum of Australia Conference on Australian History, 24-25 April 1982, Museum of Australia, ACT, nd; Patricia M. Summerfield, Proceedings of the Council of Australian Museum Associations Conference, Perth, WA, 1986, History Department, Western Australian Museum, 1987; and Margaret Anderson, 'Selling the past: history in museums in the 1990s', in John Rickard and Peter Spearritt (eds), Packaging the Past? Public History, a special edition of Australian Historical Studies, vol 24, no 96, April 1991, pp130-141.

4 Partly relevant (because it mainly deals with collected rather than museum-generated archives) is Bruce Smith, 'Archives in museums', Archives and Manuscripts, vol 23, no 1, May 1995, pp38-47.

5 Gaynor Kavanagh, Making Histories in Museums, Leicester Univeristy Press, London, 1996, pp3-4.

6 Janis Wilton, 'Museums and memories: remembering the past in local museums', Public History Review, vol 12, 2006, pp58-79.

${ }^{7}$ Ivan Karp, 'Museums and communities: the politics of public culture', in Ivan Karp et al, Museums and Communities: the Politics of Public Culture, Smithsonian Institution Press, Washington and London, 1992, pp1-17.

8 Michael Piggott, 'The history of Australian record-keeping: a framework for research', Australian Library Journal, vol 47, November 1998, pp343-354; Michael Piggott, 'Archives and Australian history', Bulletin of the Australian Historical Association, vol 90, June 2000, pp4-11.

${ }^{9}$ Helen Nosworthy, 'Reaching out: a core program for Australian archives', in Sue McKemmish and Michael Piggott (eds), The Records Continuum: lan Maclean and Australian Archives' First Fifty Years, Ancora Press, Clayton, 1994, pp64-77. See also Catherine Nicholls, 'The role of outreach in Australian archive programs,' Archives and Manuscripts, vol 29, no 1, 2001, pp62-70; and Barbara Craig, 'What are the clients? Who are the products? The future of archival public services in perspective', Archivaria, vol 31, Winter 1990-1, pp13541.

${ }^{10}$ Not all of it deals specifically with exhibitions, but see: 'Supplement: public programs in archives', Archivaria, vol 31, Winter 1990-1, pp91-141; Gabrielle Hyslop, 'For many audiences: developing public programs at the National Archives of Australia', Archives and Manuscripts, vol 30, no. 1, May 2002; Catherine Nicholls, 'The role of outreach in Australian archive programs'; Catherine Nicholls, 'Exhibiting evidence', Archivaria, vol 55, Spring 2003, pp27-42; Helen Nosworthy, 'Reaching out'; Ann Pedersen, 'User education and public relations', in Ann Pedersen (ed), Keeping Archives, 311-353 (see also her chapter in Judith Ellis (ed.) Keeping Archives, second edition, D.W. Thorpe, Port Melbourne, 1993, pp306-49); Christopher Weir, 'The marketing context. Outreach: luxury or necessity?', Journal of the Society of Archivists, vol 25, no 1, 2004, pp72-77; Christine Yeats, 'Public programs: all this reaching out but are we connecting with anyone?', paper presented at the meeting of the Australian Society of Archivists' Reference and Public Programs Special Interest Group, October 2005. Available: http://www.archivists.org.au/pubs/newsletters/rappsig200512.pdf(accessed 23 April 2006).

${ }^{11}$ On the AWRS, see: Michael Piggott, 'The Australian War Records Section and its aftermath, 1917-1925', Archives and Manuscripts, vol 8, no 2, December 1980, pp41-50; Simon Cooke and Anna Froude, 'The Australian War Records Section', paper presented as part of the Australian War Memorial's Summer Scholarship Scheme, 1989; and Michael McKernan, Here is Their Spirit.

${ }^{12}$ Tim Cook, 'Documenting war and forging reputations: Sir Max Aitken and the Canadian War Records Office in the First World War', War in History, vol 10, no 3, 2003, pp265-295; Robert McIntosh, 'The Great War, archives and modern memory', Arhivaria, vol 46, Fall 1998, pp1-31, especially 11-13.

${ }^{13}$ Charles Bean, diary entry 20 November 1917, AWM38: 3DRL 606/94/2. (All archival material referred to in this article is held at the Australian War Memorial.)

${ }^{14}$ Charles Bean, 'Australia's records preserved as sacred things: pictures, relics and writings', The Anzac Bulletin, no 40, 10 October 1917, p14.

${ }^{15}$ Parliamentary Standing Committee on Public Works, Report Together with Minutes of Evidence Relating to the proposed Australian War Memorial, Canberra, Parliament of the Commonwealth of Australia, Canberra, 1928, p8.

${ }^{16}$ Anne-Marie Condé, 'A marriage of sculpture and art: dioramas at the Memorial', Journal of the Australian War Memorial, no19, November 1991, pp56-9.

${ }^{17}$ EXDOC034 
${ }^{18}$ Treloar, 'Australia's war records. How they were collected. What will become of them', draft of an article for Life magazine, AWM93: 20/1192.

${ }^{19}$ Talk given to members of the Footscray RSL, 19 March 1934, copy in author's possession, original with Alan Treloar, Armidale, NSW, February 2006.

20 'Report on the work of the Australian War Records Section from May 1917 to September 1918 by the officerin-charge', p11, AWM224: MSS553.

21 'Lecture given by Colonel J.L. Treloar' as part of a training course for administrative officers of the Commonwealth Public Service, November-December 1950, AWM315: 207/001/019.

${ }^{22}$ Lodgings: Charles Bean, diary January-February 1918, AWM38: 3DRL 606/97/2; 'night after night': Charles Bean, 'The beginnings of the Australian War Memorial', p11, AWM38: 3DRL 6673/619.

${ }^{23}$ Charles Bean, 'The Australian War Records', March 1918, AWM38: 3DRL 6673/362.

${ }_{25}^{24}$ C.E.W. Bean, In your hands Australians, Cassell and Co, London, 1918, p60.

${ }^{25}$ Charles Bean, 'Further memoir, together with appendices, by C.E.W. Bean... concerning official records and history of the Australian Imperial Force...', April 1919, Appendix Q, AWM93: 2/5/7[A]; Bean touches again on these ideas in a letter to Treloar on 31 January 1920 - see AWM93: 12/5/48.

${ }^{26}$ Bean, 'The beginnings of the Australian War Memorial', p15.

${ }_{27}$ See the series notes for official records series AWM51, 'Confidential and security classified records originally maintained by the Australian War Memorial Library'. Available: http://naa12.naa.gov.au/scripts/SeriesDetail.asp?M=3\&B=AWM51 (accessed 17 July 2006).

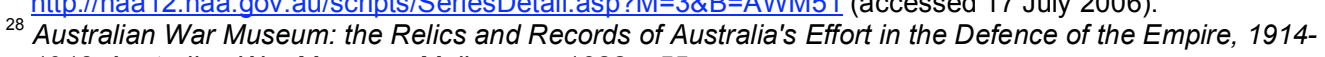
1918, Australian War Museum, Melbourne, 1922, p55.

${ }^{29}$ See correspondence between Treloar and Bean, October 1926, AWM93: 12/1/83. Treloar had another go years later, in December 1937. He put a proposal to publish a book of documents to the Finance Committee of the Memorial's Board of Management, and it was approved, but again the project seems to have lapsed. See: Minutes for the 28th meeting of the Finance Committee, AWM170, 2/29. On the production of books of documents generally, see Kennneth Binns, 'Publication of historical records in Australia', Historical Studies Australia and New Zealand, vol 1, no. 2, October 1940, pp91-96; and Brian Fletcher, Australian History in New South Wales 1888 to 1938, UNSW Press, Kensington, 1993, pp58-75.

${ }_{30}$ Parliamentary Standing Committee on Public Works, Report together with minutes of evidence, p5.

${ }^{31}$ Known after October 1923 as Australian War Memorial. See McKernan, Here is Their Spirit, p78.

${ }^{32}$ Australian War Museum: the Relics and Records; the Sydney editions had the same title.

${ }^{33}$ Letter, Charles Bean to John Treloar, 4 September 1920, AWM38: 3DRL 6673/766. The document is probably EXDOC053.

${ }^{34}$ Handwritten note, Treloar to AWM staff, 6 June 1921, AWM25: 367/240.

${ }^{35}$ Letter, Treloar to Arthur Bazley, 5 February 1921, AWM38: 3DRL 6673/766.

${ }^{36}$ Original records and captions prepared for the Melbourne exhibition opening of the War Memorial Museum in 1922, EXDOC186.

37 'Australian War Memorial Museum: inventory of exhibits, revised November 1929', AWM333.

${ }^{38}$ This affirms Craig Melrose's assertion that in the Memorial's early exhibitions there was tendency towards 'triumphal commemoration' and a desire to prove Australian military supremacy. See Melrose, 'A praise that never ages', p14, 26.

${ }^{39}$ EXDOC186, sheet 23, items 1 and 2 .

${ }^{40}$ EXDOC186, sheet 21 , item 1 .

${ }^{41}$ EXDOC186, sheet 3, item 1.

42 'Australian War Record Section trophy description registers', AWM333.

${ }^{43}$ EXDOC186, sheet 15 item 1. Relics and Records, Melbourne, p29.

${ }^{44}$ EXDOC 186, sheet 1 item 2.

45 'Australian War Memorial Museum: inventory of exhibits...', pp34, 126-130, AWM333.

${ }^{46}$ This item also appears on Bean's 1920 list: letter, Bean to Treloar, 4 September 1920, AWM38: 3DRL 6673/766.

${ }^{47}$ Relics and Records, Sydney, twelfth impression, November 1929, p11.

48 'Australian War Memorial Museum: inventory of exhibits...', p17, AWM333.

${ }^{49}$ ART09633.

50 'Australian War Memorial Museum: inventory of exhibits...', p17; EXDOC186 sheet 27. Evacuation is accessioned as ART41017.

${ }^{51}$ Relics and Records, Sydney, 12th impression, November 1929, p13.

${ }^{52}$ Relics and Records, Sydney, 12th impression, November 1929, p[4].

${ }^{53}$ Kimberley Webber, 'Constructing Australia's past: the development of historical collections 1888-1938', in Summerfield, Proceedings of the Council of Australian Museum Associations Conference, pp 155-173.

${ }_{55}^{54}$ Melrose, 'A praise that never ages', pp30-1.

${ }^{55}$ Healy, From the Ruins of Colonialism, pp77-105.

${ }^{56}$ EXDOC185, item 11 sheet 1.

${ }^{57}$ 'Australian War Memorial Museum: inventory of exhibits... ', p17; EXDOC186, sheet 21 item 1.

${ }^{58}$ Herald, 22 April 1922.

${ }^{59}$ Relics and Records, Sydney, 15th impression, April 1933, p3; and report by the Director to the Board of Management, 19 March 1934, AWM170: 1/22. See Melrose, 'A praise that never ages', pp2-3 for a 
comparison of attendance with population figures, and with attendances at other museums.

${ }^{60}$ As a scan of the 1929 inventory shows. The removal might have been prompted by the fact that the documents had long been exposed to light. Also, the building housing the exhibition was infested with silverfish and was not rain-proof. Treloar feared for the safety of the paper items. See the Director's report to the Board of Management, 12 June 1930, AWM170: 1/15.

${ }^{61}$ The numbers go to EXDOC186, some items having been withdrawn.

62 EXDOC118, EXDOC130, EXDIC156 and EXDOC146.

${ }^{63}$ EXDOC178.

${ }^{64}$ EXDOC095.

${ }^{65}$ EXDOC067, EXDOC069, EXDOC078, and letter, Treloar to the Acting Director, Australian War Memorial (Bazley), 7 May 1946, AWM315: 748/011/002.

${ }^{66}$ EXDOC177; memos, Treloar to AWM staff, 13 April 1947 and 12 July 1947, AWM315: 419/013/001.

${ }^{67}$ See especially Hilary Jenkinson, 'The English Archivist: a New Profession', in Alan Sutton (ed), Selected Writings of Hilary Jenkinson, Alan Sutton Publishing Limited, Gloucester, 1980, p239.

${ }^{68}$ Paul Hasluck, opening address in Promoting the better use of archives in Australia: papers from the 1981 Conference of the Australian Society of Archives, Australian Society of Archives, ACT, 1981, pp1-2. For a discussion of Hasluck's views, see Colin Smith, 'Some reflections on Sir Paul Hasluck's 'narrow and rigid view of archives' ', Archives and Manuscripts, vol 11, no. 1, May 1983, pp47-52.

69 Herald, 12 January 1954.

${ }^{70}$ EXDOC040, and 'Lecture given by Colonel J.L. Treloar', AWM315: 207/001/019.

${ }^{71}$ Roneod insert to the Guide to Australian War Memorial, Canberra, Australian War Memorial, Canberra, 1953. Copy of insert held by Brad Manera, Canberra.

72 Letter, Bean to his parents, 27 November 1916, AWM38, 3DRL 6673/899 parts 1-3; quoted in Denis Winter, Making the legend: the war writings of C.E.W. Bean, Queensland University Press, St Lucia, $1992, \mathrm{p} 10$.

${ }^{73}$ Quoted in Crista Bradley, 'Mediate, mediate, celebrate: public programming in a postmodern world', Archives and Manuscripts vol 34, number 2, November 2006, pp. 176-77. See also James O'Toole, 'The symbolic significance or archives', American Archivsit, vol 56, no 2, Spring 1993, pp234-255.

${ }^{74}$ Hugh Taylor, "'Heritage" revisted: documents as artefacts in the context of museums and material culture', Archivaria, vol 40, Fall 1995, pp8-20.

${ }^{75}$ Now the National Archives of Australia.

${ }^{76}$ Nosworthy pp68-9.

77 ibid.

${ }^{78}$ Gabrielle Hyslop, 'From warehouse to treasure house: changing the public face of the National Archives of Australia', paper delivered at the Association of Local and Private Archives in Norway, Oslo Conference on Archives and Outreach Work, February 2005, p2 (copy in author's possession). 